\title{
EVALUATION OF GLUTATHIONE REDUCTASE (GR) ACTIVITY IN LIVER OF FISH, CHANNA PUNCTATUS (BLOCH, 1793) EXPOSED TO HEXAVALENT CHROMIUM
}

\author{
Yashika Awasthi ${ }^{1}$ \& Sunil P. Trivedi ${ }^{*}$ \\ ${ }^{1}$ Environmental Toxicology \& Bioremediation Laboratory, \\ Department of Zoology, University of Lucknow, Lucknow-226007, India \\ (*corresponding author) \\ Email ID: trivedi_sp@lkouniv.ac.in; sat060523@gmail.com
}

ABSTRACT: Antioxidant defence system is known to be a sensitive biomarker of metal exposure widely employed in predicting toxicity after sub-lethal exposure of $\mathrm{Cr}^{6+}$ in fish. The present study conducted to assess the impact of $\mathrm{Cr}^{6+}$ on Glutathione reductase (GR) activity in liver of fish, Channa punctatus. Fish were exposed to two different sub-lethal concentrations of $\mathrm{Cr}^{6+} v i z ., 3.93 \mathrm{mg} / \mathrm{L}\left(5 \%\right.$ of $\left.96 \mathrm{~h} \mathrm{LC}_{50}\right)(\mathrm{T} 1)$ and $7.85 \mathrm{mg} / \mathrm{L}\left(10 \%\right.$ of $\left.96 \mathrm{~h} \mathrm{LC}_{50}\right)(\mathrm{T} 2)$ along with one control group without any toxicant exposure, for 15, 30 and $45 \mathrm{~d}$. Results showa significant $(p<0.05)$ increase in GR activity with an increase in dose and exposure period. This study emphasized the role of GR in monitoring of metal toxicity in aquatic regimes as an early warning tool.

KEYWORDS: $\mathrm{Cr}^{6+}$, Channa punctatus, Glutathione reductase, Liver, Antioxidant.

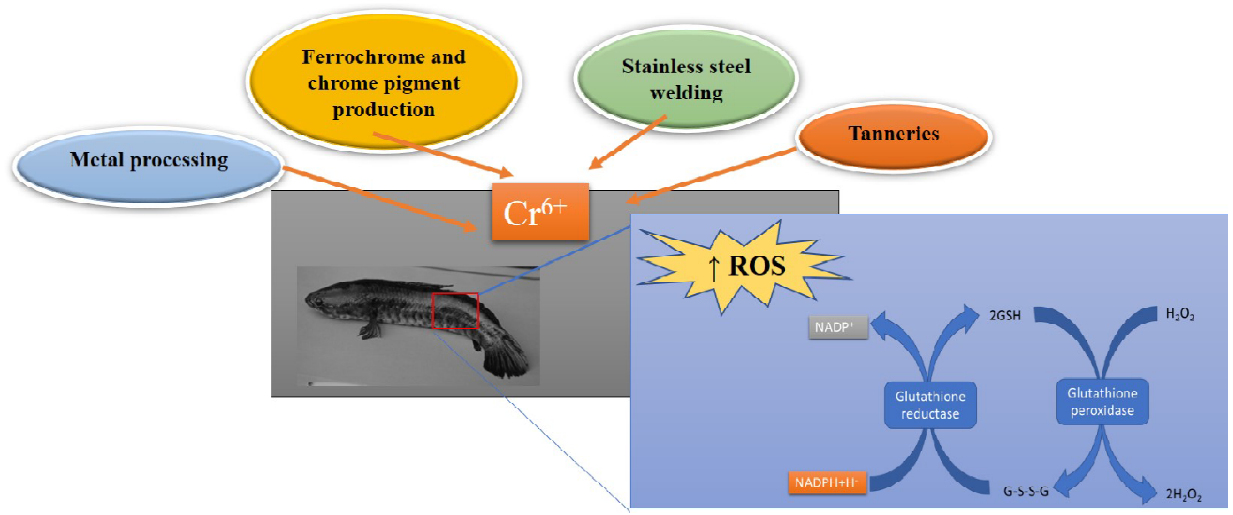

\section{INTRODUCTION}

Biomonitoring of metal pollution in aquatic ecosystem is important in many aspects and is very often done in sentinel organisms like fishes because they provide an insight about the manifestation of toxicant induced stress. Use of fish in this kind of toxicological studies have a reason because consumption of fish contaminated with metals harshly affects human health. Among all contaminants, heavy metals are significant environmental toxicants due to their non-biodegradable nature. Chromium mainly exists in two valence state i.e., $\mathrm{Cr}^{3+}$ and $\mathrm{Cr}^{6+}$ in environment. In comparison to $\mathrm{Cr}^{3+}, \mathrm{Cr}^{6+}$ is more toxic and a potent human carcinogen ${ }^{1}$. According to Environmental 
Protection Agency (EPA), $\mathrm{Cr}^{6+}$ is listed as one of the priority pollutant at $129^{\text {th }}$ rank. It also comes under 14 most noxious heavy metals due to its wider application in industries like electroplating, stainless steel production, tanning and textile manufacturing; consequently, $\mathrm{Cr}^{6+}$ gets easily discharged into aquatic ecosystem ${ }^{2}$. When released to land, $\mathrm{Cr}^{6+}$ compounds bind to soil and in water these compounds are very continual as sediments, with a high potential for accumulation in aquatic life ${ }^{3}$. $\mathrm{Cr}^{6+}$ produces cytotoxicity and detrimental impact on behaviour of fish such as hypertrophy and paraplegia in gill epithelium, uneven swimming and suspended feeding ${ }^{4}$.

For long, fishes are being used as a genetic model to elucidate toxicological mechanisms induced by contaminants for hazard identification in humans via readacross. Moreover, these mechanisms are not only conserved among fish species but also between other vertebrates including mammals and even humans ${ }^{5}$. Fish, Channa punctatus is becoming increasingly important in toxicological research, particularly in South-east Asian countries, due to its availability throughout the year, easy maintenance in aquaria, a broad range of responsiveness and sensitivity against a variety of aquatic pollutants ${ }^{6,7}$.

The toxicity of $\mathrm{Cr}^{6+}$ in biological systems is closely related with greater generation of reactive oxygen species $(\mathrm{ROS})^{8,9}$. Superoxide $\left(\mathrm{O}^{\prime \prime 2}\right)$, one of the parental forms of intracellular ROS, is highly reactive molecule, but it can be converted to $\mathrm{H}_{2} \mathrm{O}_{2}$ that is produced by the action of superoxide dismutase (SOD)and reduced to water by catalase (CAT) and glutathione reductase $(\mathrm{GR})^{10,11}$. GR catalyses the reduction of oxidized glutathione (GSSG) to glutathione (GSH) and it is essential for the glutathione redox cycle that maintains adequate levels of reduced cellular $\mathrm{GSH}^{12}$. GSH plays a critical role in protecting cells from oxidative damage, toxicity of xenobiotic electrophiles and maintaining redox homeostasis ${ }^{13} \cdot \mathrm{Cr}^{6+}$ induced oxidative stress has already been reported in goldfish tissues wherein it affected the activity of antioxidant defence system and associated enzymes ${ }^{14}$. The response of GR activity could help to predict metal toxicity in the aquatic environments and be useful as an "early warning tool" in natural monitoring studies.

\section{MATERIA S AND METHODS}

\subsection{Test organism and acclimatization:}

Fish specimens $(14 \pm 1.0 \mathrm{~cm} ; 35 \pm$ $3.0 \mathrm{~g}$ ) of Channa punctatus (Bloch, 1793), a common pond murrel (class Actinopterygii, order - Perciformes, family - Channidae), were procured from lentic habitats of Lucknow by the aid of fishermen. Fish were placed in aquarium for the prophylactic treatment with $0.05 \% \mathrm{KMnO}_{4}$ for 2-5 min to avoid dermal infections and acclimatized to laboratory condition $(\mathrm{pH} 6.8$ \pm 0.1 , temperature $27 \pm 3^{\circ} \mathrm{C}$, dissolved oxygen (DO) $7.1 \mathrm{mg} / \mathrm{L}$, total dissolved solids (TDS) $197.89 \mathrm{mg} / \mathrm{L}$ and hardness 
72.90 as $\mathrm{CaCO}_{3} \mathrm{mg} / \mathrm{L}$ ) for 15 days following the standard procedure ${ }^{15}$. Fish were fed twice a day with fresh goat liver and commercial aquarium food pellets. The faecal matter and other waste material were removed daily from aquaria.

\subsection{Test Chemical:}

Chromium trioxide $\left(\mathrm{Cr}^{6+}\right)$, Batch no. T-8371997, manufactured by Sisco-Research Laboratories Pvt. Ltd., Navketan Industrial Area, Mumbai, India-400069 was purchased through a local dealer. All chemicals used during experiment are of analytical grade.

\subsection{Determination of $\mathrm{LC}_{50}$ of Chromium trioxide:}

Fish were exposed to different concentrations of $96 \mathrm{~h}-\mathrm{LC}_{50}$ of the $\mathrm{Cr}^{6+}$ which was already worked out by Awasthi et al., $2018^{16}$. It was $78.54 \mathrm{mg} / \mathrm{L}$ with $95 \%$ lower and upper confidence limits of 68.14 and $90.53 \mathrm{mg} / \mathrm{L}$, respectively.

\subsection{Experimental design:}

The acclimatized fish were randomly divided into three groupsviz., group 1 as control, group 2 (T1) and group 3 (T2) as treated groups, each comprising three replicates. The $96 \mathrm{~h}-\mathrm{LC}_{50}$ of $\mathrm{Cr}^{6+}$ was assessed and used as a reference for the selection of sub-lethal concentrations of treated groups (T1 and T2). For the estimation of Glutathione reductase (GR) activity, fishes of groups (T1 and T2) were exposed to $3.93 \mathrm{mg} / \mathrm{L}$ and $7.85 \mathrm{mg} / \mathrm{L}$ corresponding to $5 \%$ and $10 \%$ of $96 \mathrm{~h}-\mathrm{LC}_{50}$ of Chromium trioxide respectively for 45 days of experimental period. After the termination of exposure period, tissue sampling was done after 15,30 and $45 \mathrm{~d}$ and 3 fish from each replicate were euthanized for the removal of liver tissue on each sampling day during experimentation. Fish were fed twice a day after every $7 \mathrm{~d}$ interval with commercial fish food. Experiments were performed under semi-static conditions and the aquaria water was changed every $24 \mathrm{~h}$ with $7 \mathrm{~d}$ aged tap water containing relative chromium concentration ${ }^{17}$.

\subsection{Biochemical Analysis: Glutathione reductase (GR) activity}

Dissected tissues were weighed and homogenized in homogenization buffer (HB; $0.32 \mathrm{M}$ sucrose, $1 \mathrm{mM}$ EDTA, $10 \mathrm{mM}$ Tris$\mathrm{HCl}$ and $\mathrm{pH}$ 7.4) in a proportion of $1: 10$ $(w / v)$. After the homogenization, cell suspension was taken in $10 \mathrm{~mL}$ falcon tubes and centrifuged at $1600 \mathrm{rpm}$ for $10 \mathrm{~min}$ at $4^{\circ} \mathrm{C}$ followed by two times washing. Once more, HB was dissolved in pellet and centrifuged at $1600 \mathrm{rpm}$ for $10 \mathrm{~min}$ at $4^{\circ} \mathrm{C}$. Finally, pellet was suspended in $500 \mu \mathrm{L}$ lysis buffer $(0.1 \mathrm{mM}$ Tris-HCl, $5 \mathrm{mM}$ EDTA, $1 \%$ SDS, $1 \% \beta$-mercaptoethanol and $\mathrm{pH}$ $8.0)$ to which $1 \mathrm{mM}$ Phenylmethylsulfonyl fluoride (PMSF) and $1 \mathrm{mM}$ Dithiothreitol (DTT) were added as $10 \mu \mathrm{L}$ vol. of each chemical and then the whole mixture was vortexed. Subsequently, the cell suspension was incubated for $30 \mathrm{~min}$ at $4^{\circ} \mathrm{C}$ and centrifuged at $16,000 \mathrm{rpm}$ for $15 \mathrm{~min}$ at $4^{\circ} \mathrm{C}$. Eventually, post mitochondrial supernatant or cell lysate was collected for 
further analyses of glutathione reductase.

The activity of Glutathione Reductase (GR) was determined by measuring NADPH oxidation at $340 \mathrm{~nm}^{18}$. The reaction mixture comprises of $600 \mu \mathrm{L}$ of buffer $(0.1 \mathrm{M}$ potassium phosphate $+0.5 \mathrm{mM}$ EDTA + $0.1 \mathrm{mM} \mathrm{KCl} ; \mathrm{pH} 7.5), 100 \mu \mathrm{L}$ of $0.1 \mathrm{mM}$ $\mathrm{NADPH}, 100 \mu \mathrm{L}$ of $\mathrm{H}_{2} \mathrm{O}$ and $100 \mu \mathrm{L}$ of supernatant of liver tissue. After the preincubation for $5 \mathrm{~min}$ at $37^{\circ} \mathrm{C}$, the reaction was initiated by adding 100 iL of $1 \mathrm{mM}$ glutathione disulphide (GSSG). The GR activity was estimated by using UV-VIS spectrophotometer (Shimadzu, UV-1800 pharma spec), and is expressed as $\mu \mathrm{g} \mathrm{mg}^{-1}$ of protein.

\subsection{Statistical Analysis:}

All data were statistically analysed at $p<0.05$. They were presented as mean \pm standard error mean (S.E.M.). The variations in values of control and treated groupsdifferences were assessed by one-way analysis of variance (ANOVA) followed by Tukey's post hoc test. All statistical analyses were carried out using SPSS software (version 20.0, Chicago, IL, USA).

\section{RESULTS AND DISCUSSION}

The present study aimed to elucidate the toxicity of $\mathrm{Cr}^{6+}$ in liver of fish, Channa punctatus. $\mathrm{Cr}^{6+}$ is regarded as a human carcinogen ${ }^{19,20}$. In vivo, $\mathrm{Cr}^{6+}$ enters into the cell by anion transporter mechanism, then reduces into different valence form ${ }^{21}$. This reduction process and various reduced states of $\mathrm{Cr}^{6+}$ lead to Reactive oxygen species
(ROS) production ${ }^{22}$. The ROS species have been found to be implemented into various signalling processes; however, increasing intracellular levels found to be associated with activation of defence system in organism system. In usual course, the antioxidant enzymatic system protects organisms from the toxic effects of the activated oxygen species and helps to maintain cellular homeostasis by removing $\operatorname{ROS}^{23}$. As a matter of fact,the antioxidant defence system of an organism works at two levels, enzymatic and nonenzymatic systems. The enzymatic system comprises of superoxide dismutase (SOD), Catalase (CAT), glutathione peroxidase (GPx) and glutatione reductase (GR) while nonenzymatic system includes several low molecular weight scavengers of these reactive species. Among the enzymatic system, the first level of defence system is created by SOD and CAT while second level of defence system is created by GPx and GR. Among these two, GR plays an important role in maintaining the level of GSH whichdirectly involves in reduction process of $\mathrm{Cr}^{6+}$ when it enters into the cellular system of organism ${ }^{24}$.

The activity of GR in liver of fishes of treated groups (T1 and T2) as compared to unexposed fish for defined exposure intervals were depicted in Fig. 1 and Table.1. The activity of GR was found to be significantly $(p<0.05)$ raised with an increase in a dose- and time-dependent manner. Compared to unexposed group, the activities of GR in liver increased from 
$5.04 \%$ to $32.98 \%$ for $\mathrm{T} 1$ and from $14.42 \%$ to $47.49 \%$ for $\mathrm{T} 2$ group with an increase of exposure time after the onset of the experiment. On the basis of percentage change in GR activity, it shows its higher sensitivity against the oxidative damages in liver of fish, Channa punctatus intoxicated with $\mathrm{Cr}^{6+}$ chronically.

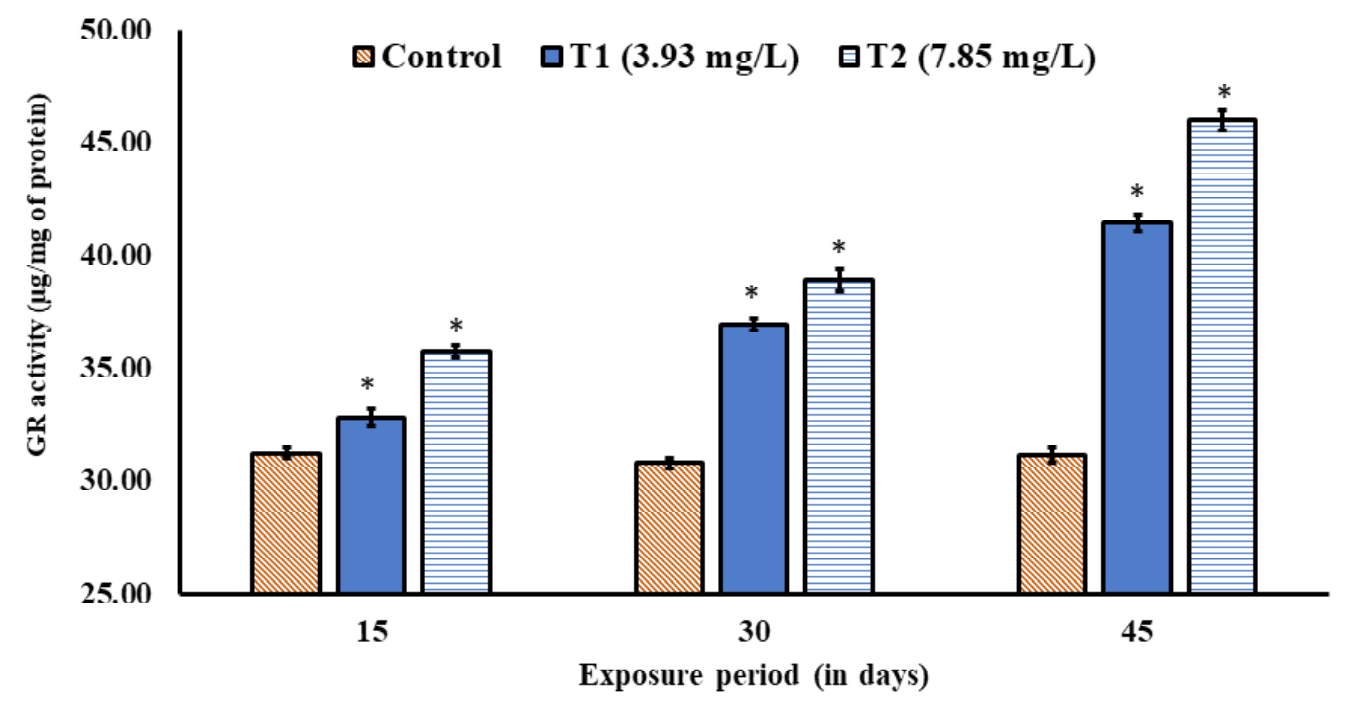

Fig. 1 The activity of GR enzyme in $\mathrm{Cr}^{6+}$ induced liver tissues of treated groups (T1=3.93 mg/ $\mathrm{L}$ and $\mathrm{T} 2=7.85 \mathrm{mg} / \mathrm{L}$ ) and in control group (C) for 15,30 and $45 \mathrm{~d}$ of exposure period. The data represent mean \pm SEM $(\mathrm{n}=3)$ of three replicates of each group $\left(^{*} p<0.05\right.$ indicate significant difference as compared to respective control group (C).

Table.1 The activity of GR enzymes (in $\mu \mathrm{g} / \mathrm{mg}$ of protein) in liver of treated groups of fishes, T1 and T2, as compared to unexposed control group after 15, 30 and $45 \mathrm{~d}$ of exposure.

Table.1 Activity of GR measured in liver tissue in fish, Channapucntatus

\begin{tabular}{|l|c|c|c|c|}
\hline \multirow{2}{*}{ Oxidative stress marker } & \multirow{2}{*}{$\begin{array}{c}\text { Exposed } \\
\text { groups }\end{array}$} & \multicolumn{3}{|c|}{ Exposure periods (d) } \\
\cline { 3 - 5 } & GR activity & $\mathbf{1 5}$ & $\mathbf{3 0}$ & $\mathbf{4 5}$ \\
\hline \multirow{2}{*}{$\boldsymbol{\mu g} / \mathbf{m g}$ of protein) } & Control & $31.22 \pm 0.24$ & $30.78 \pm 0.23$ & $31.16 \pm 0.33$ \\
\cline { 2 - 5 } & $\mathrm{T} 1(3.93 \mathrm{mg} / \mathrm{L})$ & $32.79 \pm 0.39^{*}$ & $36.94 \pm 0.25^{*}$ & $41.44 \pm 0.36^{*}$ \\
\cline { 2 - 5 } & $\mathrm{T} 2(7.85 \mathrm{mg} / \mathrm{L})$ & $35.72 \pm 0.27^{*}$ & $38.90 \pm 0.50^{*}$ & $45.96 \pm 0.45^{*}$ \\
\hline
\end{tabular}

$(* p<0.05$ represent significant difference as compare to control) 
The increase in hepatic level of antioxidant enzymes is a clear indicative feature of oxidative stress. The findings of the present study revealed a significant increase in GR activity upon exposure of $\mathrm{Cr}^{6+}$. Our study is in agreement with the studies of Matos et al.,(2007) ${ }^{25}$ in which they assessed an increase in GR activity in an oxidative stress situation. Kumari et al.,(2014) ${ }^{26}$ also reported an increment in GR activity under the exposure of $\mathrm{Cr}^{6+}$ in fish, Labeorohita. Another study on brain tissues of fish, Oncorhynchus mykiss also documented the similar induction in GR activities with the significant value on exposure of chromium ${ }^{27}$. The increment in GR activity is directly linked with the reestablishment of the GSH level that is oxidised. On other hand, decline in activity of GR leads to depletion in GSH level which results in prooxidative effect. It was also reported that depletion in GSH level causes variation in GST activity under the exposure of metal ${ }^{28}$. We also find ample support from the findings of Atli and Canli, (2010) 29 who have documented variation in antioxidant enzyme activity under the exposure of different metals in fish, Oreochromis niloticus. Thus, study indicates that $\mathrm{Cr}^{6+}$ induces oxidative stress as is evident by an increment in ROS production in the liver of fish, Channa punctatus, exposed to sub-lethal concentrations of aforesaid metal.

\section{CONFLICT OF INTEREST}

Authors declare no conflict of interest

\section{ACKNOWLEDGMENTS}

Yashika Awasthi is grateful to the University Grants Commission (UGC), New Delhi, India for providing BSR-fellowship (File No. 25-1/2014-2015 (BSR)/7-109/ 2007/BSR). We record our sincere thanks to the UGC, New Delhi for providing Special Assistance Programme (SAP) and Department ofScience and Technology, Government of India for providing FIST and PURSE Programmes. We are also grateful to Head, Department of Zoology, University of Lucknow, Lucknow (226 007) for providing laboratory facilities.

\section{REFERENCES}

1. IARC, 2018. IARC (International Agency for Research on Cancer).

2. Shaw, P., P. Mondal, A. Bandyopadhyay, A. Chattopadhyay, 2019. Environmentally relevant concentration of chromium activates $\mathrm{Nrf} 2$ and alters transcription of related XME genes in liver of zebrafish. Chemosphere 214:35-46. https://doi.org/10.1016/ j.chemosphere.2018.09.104.

3. Velma, V., P.B. Tchounwou, 2011. Hexavalent chromium-induced multiple biomarker responses in liver and kidney of goldfish, Carassius auratus. Environ Toxicol., 26:64956. https://doi.org/10.1002/tox.20602.

4. Aslam, S., A.M. Yousafzai, 2017. Chromium toxicity in fish: A review article. $\sim 1483 \sim J$ Entomol Zool Stud., 5:1483-1488.

5. Cossins, A.R., D.L. Crawford, 2005. Fish as models for environmental genomics. Nat Rev Genet., 6:324-33. https://doi.org/10.1038/ $\operatorname{nrg} 1590$.

6. Ratn, A., R. Prasad, Y. Awasthi, et al, 2018. Zn $2+$ induced molecular responses associated with oxidative stress, DNA damage and histopathological lesions in liver and kidney 
of the fish, Channa punctatus (Bloch, 1793). Ecotoxicol Environ Saf 151:10-20. https:// doi.org/10.1016/j.ecoenv.2017.12.058.

7. Shukla, A., S.P. Trivedi, 2017. Anionic Surfactant, Linear Alkyl Benzene Sulphonate Induced Oxidative Stress and Hepatic Impairments in Fish Channa punctatus. Proc Zool Soc., 1-8. https://doi.org/10.1007/ s12595-017-0223-1.

8. Awasthi, Y., A. Ratn, R. Prasad, et al, 2019. A protective study of curcumin associated with Cr6+ induced oxidative stress, genetic damage, transcription of genes related to apoptosis and histopathology of fish, Channa punctatus (Bloch, 1793). Environ Toxicol Pharmacol., 71:103209. https://doi.org/ 10.1016/j.etap.2019.103209.

9. Husain, N., R. Mahmood, 2017. Hexavalent chromium induces reactive oxygen species and impairs the antioxidant power of human erythrocytes and lymphocytes: Decreased metal reducing and free radical quenching ability of the cells. Toxicol Ind Health, 33:623-635. https://doi.org/10.1177/ 0748233717703892.

10. Birben, E., U.M. Sahiner, C. Sackesen, et al, 2012. Oxidative Stress and Antioxidant Defense. World Allergy Organ J 5:9-19. h t t p s : // doi . org/10.1097/ WOX.0b013e3182439613.

11. Ratn, A., Y. Awasthi, M. Kumar, et al, 2017. Phorate induced oxidative stress, DNA damage and differential expression of p53, apaf-1 and cat genes in fish, Channa punctatus (Bloch, 1793). Chemosphere. h t t p s://doi.org/10.1016/ j.chemosphere.2017.05.008.

12. Eroglu, A., Z. Dogan, E.G. Kanak, et al, 2015. Effects of heavy metals $(\mathrm{Cd}, \mathrm{Cu}, \mathrm{Cr}, \mathrm{Pb}, \mathrm{Zn}$ ) on fish glutathione metabolism. Environ Sci Pollut Res., 22:3229-3237. https://doi.org/ 10.1007/s11356-014-2972-y.

13. Forman, H.J., H. Zhang, A. Rinna, 2009. Glutathione: Overview of its protective roles, measurement, and biosynthesis. Mol Asp Med., 30:1-12. https://doi.org/10.1016/ j.mam.2008.08.006.

14. Kubrak, O.I., O.V. Lushchak, J.V. Lushchak, et al, 2010. Chromium effects on free radical processes in goldfish tissues: Comparison of $\mathrm{Cr}(\mathrm{III})$ and $\mathrm{Cr}(\mathrm{VI})$ exposures on oxidative stress markers, glutathione status and antioxidant enzymes. Comp Biochem Physiol - C Toxicol Pharmacol., 152:360-370. https:/ /doi.org/10.1016/j.cbpc.2010.06.003.

15. APHA A. and W., 2012. Standard Methods for the Examination of Water and Waste water, 22nd Editi. American Public Health Association, 2012, New York Washington D.C.

16. Awasthi, Y., A. Ratn, R. Prasad, et al, 2018. An in vivo analysis of $\mathrm{Cr} 6+$ induced biochemical, genotoxicological and transcriptional profiling of genes related to oxidative stress, DNA damage and apoptosis in liver of fish, Channa punctatus (Bloch, 1793). Aquat Toxicol 200:158-167. https:// doi.org/10.1016/j.aquatox.2018.05.001.

17. Palermo, F.F., W.E. Risso, J.D. Simonato, C.B.R. Martinez, 2015. Bioaccumulation of nickel and its biochemical and genotoxic effects on juveniles of the neotropical fish Prochilodus lineatus. Ecotoxicol Environ Saf., 116:19-28. https://doi.org/10.1016/j.ecoenv.2015.02.032.

18. Carlberg, I., B. Mannervik, 1975. Purification and Characterization of the Flavoenzyme Glutathione Reductase from Rat Liver. $J$ Biol. Chem., 250:5475-5480.

19. Gupta, A.K., I. Ahmad, M. Ahmad, 2014. Genotoxicity of refinery waste assessed by some DNA damage tests. Ecotoxicol Environ Saf., 1-7. https://doi.org/10.1016/ j.ecoenv.2014.03.032

20. Zewail TM, Yousef NS, 2014. Chromium ions (Cr6+ \&amp; Cr3+) removal from synthetic wastewater by electrocoagulation using vertical expanded $\mathrm{Fe}$ anode. J Electroanal Chem 735:123-128. https://doi.org/10.1016/ J.JELECHEM.2014.09.002.

21. Fernández, P.M., S.C. Viñarta, A.R. Bernal, et al, 2018. Bioremediation strategies for chromium removal: Current research, scale- 
up approach and future perspectives. Chemosphere 208:139-148. https://doi.org/ 10.1016/j.chemosphere.,2018.05.166.

22. Feng, M., H. Yin, H. Peng, et al, 2017. Hexavalent chromium induced oxidative stress and apoptosis in Pycnoporus sanguineus. Environ Pollut., 228:128-139. https://doi.org/10.1016/j.envpol.2017.05.012.

23. Hu, S.,W. Zhang, J. Li, et al, 2016. Antioxidant and gene expression responses of Eisenia fetida following repeated exposure to BDE209 and $\mathrm{Pb}$ in a soil-earthworm system. Sci Total Environ., 556:163-168. https:// doi.org/10.1016/j.scitotenv.2016.02.194.

24. Chiu, A., X.L. Shi, W.K.P. Lee, et al, 2010. Review of Chromium (VI) Apoptosis, CellCycle-Arrest, and Carcinogenesis. J Environ Sci Heal Part C, 28:188-230. https://doi.org/ 10.1080/10590501.2010.504980.

25. Matos, P., A. Fontaýnnhas-Fernandes, F. Peixoto, et al, 2007. Biochemical and histological hepatic changes of Nile tilapia Oreochromis niloticus exposed to carbaryl. Pestic Biochem Physiol., 89:73-80. https://doi.org/10.1016/ j.pestbp.2007.03.002.
26. Kumari, K., A. Khare, S. Dange, 2014. The Applicability of Oxidative Stress Biomarkers in Assessing Chromium Induced Toxicity in the Fish Labeo rohita. Hindawi Publ Corp 2014:11. https://doi.org/http://dx.doi.org/ 10.1155/2014/782493 Research.

27. Li, Z.H., P. Li, T. Randak, 2011. Evaluating the toxicity of environmental concentrations of waterborne chromium (VI) to a model teleost, oncorhynchus mykiss: a comparative study of in vivo and in vitro. Comp Biochem Physiol., Part C Toxicol Pharmacol 153:402407 . https://doi.org/10.1016/ J.CBPC.2011.01.005.

28. Elia, A.C., R. Galarini, M.I. Taticchi, et al, 2003. Antioxidant responses and bioaccumulation in Ictalurus melas under mercury exposure. Ecotoxicol Environ Saf., 55:162-167. https:/ /doi.org/10.1016/S0147-6513(02)00123-9.

29. Atli, G., M. Canli, 2010. Response of antioxidant system of freshwater fish Oreochromis niloticus to acute and chronic metal $(\mathrm{Cd}, \mathrm{Cu}$, $\mathrm{Cr}, \mathrm{Zn}, \mathrm{Fe})$ exposures. Ecotoxicol. Environ. Saf., 73:1884-1889. https://doi.org/10.1016/ j.ecoenv.2010.09.005 